\title{
Estrogen stimulates leptin receptor expression in ATDC5 cells via the estrogen receptor and extracellular signal-regulated kinase pathways
}

\author{
Shan-Jin Wang*, Xin-Feng Li*, Lei-Sheng Jiang and Li-Yang Dai \\ Department of Orthopedic Surgery, Xinhua Hospital, Shanghai Jiaotong University School of Medicine, 1665 Kongjiang Road, Shanghai 200092, China \\ (Correspondence should be addressed to L-S Jiang; Email: jiangleisheng@126.com) \\ *(S-J Wang and X-F Li contributed equally to this work.)
}

\begin{abstract}
Regulation of the physiological processes of endochondral bone formation during long bone growth is controlled by various factors including the hormones estrogen and leptin. The effects of estrogen are mediated not only through the direct activity of estrogen receptors (ERs) but also through cross talk with other signaling systems implicated in chondrogenesis. The receptors of both estrogen and leptin (OBR (LEPR)) are detectable in growth plate chondrocytes of all zones. In this study, the expression of mRNA and protein of $\mathrm{OBR}$ in chondrogenic ATDC5 cells and the effect of $17 \beta$-estradiol $\left(E_{2}\right)$ stimulation were assessed using quantitative PCR and western blotting. We have found that the mRNA of Obr was dynamically expressed during the differentiation of ATDC5 cells over 21 days. Application of $\mathrm{E}_{2}\left(10^{-7} \mathrm{M}\right)$ at day 14 for $48 \mathrm{~h}$ significantly upregulated $\mathrm{OBR}$ mRNA and protein levels $(P<0 \cdot 05)$. The

upregulation of $\mathrm{Obr}$ mRNA by $\mathrm{E}_{2}$ was shown to take place in a concentration-dependent manner, with a concentration of $10^{-7} \mathrm{M} \mathrm{E}_{2}$ having the greatest effect. Furthermore, we have confirmed that $\mathrm{E}_{2}$ affected the phosphorylation of ERK1/2 (MAPK1/MAPK3) in a time-dependent manner where a maximal fourfold change was observed at $10 \mathrm{~min}$ following application of $E_{2}$. Finally, pretreatment of the cells with either U0126 (ERK1/2 inhibitor) or ICI 182780 (ER antagonist) blocked the upregulation of OBR by $E_{2}$ and prevented the $E_{2^{-}}$ induced phosphorylation of ERK. These data demonstrate, for the first time, the existence of cross talk between estrogen and $\mathrm{OBR}$ in the regulation of bone growth whereby estrogen regulates the expression of $\mathrm{Obr}$ in growth plate chondrocytes via ERs and the activation of ERK1/2 signaling pathways. Journal of Endocrinology (2012) 213, 163-172
\end{abstract}

\section{Introduction}

The development of bones is a result of endochondral bone formation that occurs at the epiphyseal growth plate through a process whereby cartilage is formed and then remodeled into bone tissue. This complex process is regulated by several growth factors and hormones. One of the key regulators of endochondral bone development is estrogen (Perry et al. 2008). Estrogen exerts its effect via traditional genomic interactions with two nuclear receptors, namely estrogen receptor $\alpha(\operatorname{ER} \alpha(\operatorname{ESR} 1))$ and $\beta(\operatorname{ER} \beta(\operatorname{ESR} 2))$ as well as by rapid nongenomic mechanisms. Studies have demonstrated that $\operatorname{ER} \alpha$ and $\operatorname{ER} \beta$ are expressed in all zones of the growth plate (van der Eerden et al. 2002, Nilsson et al. 2002, 2003). Our recent study ( $\mathrm{Li}$ et al. 2012) observed gender- and region-specific differences in $E R \alpha$ and $E R \beta$ gene expression in the limb and spine growth plate during development in both male and female rats. The direct binding of estrogen to $E R \alpha$ and $E R \beta$ results in the initiation of signal transduction. In addition, the nongenomic mechanism has been suggested to be of importance for the regulation of bone growth (Sylvia et al. 2001, Ekstein et al. 2005, McMillan et al. 2006, Windahl et al. 2007).
Another hormone that also plays an important role in the regulation of endochondral bone formation is leptin, which modulates several stages of the process of growth plate chondrocyte differentiation, proliferation, and mineralization (Kishida et al. 2005, Bertoni et al. 2009). The direct actions of leptin are through the leptin receptor (OBR (LEPR)), which is present in the growth plate (Nakajima et al. 2003, Kishida et al. 2005). Activation of OBR by leptin leads to the activation of many signaling pathways including the JAK1/STAT1 pathway and the phosphatidylinositol 3-kinase (PI3K (PIK3R1))/MAPK1 pathway, both of which can mediate the differentiation of chondrocytes (Frubbeck 2006, Ben-Eliezer et al. 2007, Gat-Yablonski \& Phillip 2008).

Previously, there were reports showing a cross talk between leptin and estrogen in hypothalamic neurons and cancer cells (Maeso Fortuny et al. 2006, Ray et al. 2007, Gao \& Horvath 2008, Fusco et al. 2010). In addition, 17 $\beta$-estradiol $\left(\mathrm{E}_{2}\right)$, acting through $\mathrm{ER} \alpha$, can induce the expression of leptin in placental trophoblastic cells through genomic and nongenomic actions including the MAPK and PI3K pathways (Gambino et al. 2010). In rodents, ovariectomy reduces $\mathrm{Obr}$ expression in the hypothalamus but increases $\mathrm{Obr}$ 
expression in subcutaneous adipose tissue, and such effects can be reversed by estrogen treatment (Mayes \& Watson 2004, Meli et al. 2004, D'Eon et al. 2005).

The fact that the expressions of ERs and Obr coexist in the growth plate and that both estrogen and leptin play a role in the regulation of chondrocyte differentiation suggests that the two hormones may interact during longitudinal bone growth. However, the direct effect of estrogen on OBR in the growth plate chondrocytes has not been fully elucidated. The purpose of this study was to examine how estrogen modulates the expression of $\mathrm{Obr}$ in chondrocytes. The study used mouse chondrogenic ATDC5 cells, which are an excellent in vitro model for studying the regulation of endochondral bone growth as they undergo similar differentiation processes with chondroprogenitor cells in the growth plates fully differentiating into hypertrophic chondrocytes in the presence of insulin (Snelling et al. 2010). The findings that both ERs and OBRs are expressed in ATDC5 cells (Kishida et al. 2005, Galal et al. 2008) also suggest that ATDC5 cells are an appropriate model for studying the cross talk between leptin and estrogen. In our previous study (Wang et al. 2011), we found that both $\operatorname{ER} \alpha$ and $\operatorname{ER} \beta$ were dynamically expressed during the ATDC5 cell differentiation from 4 to 21 days. Our results also indicated that leptin regulates ERs via the ERK1/2 (MAPK1/MAPK3) signaling pathway in ATDC5 cells, suggesting a cross talk between leptin and ERs in the regulation of bone formation. In this study, we hypothesized that estrogen could induce an upregulation of the expression of Obrs during chondrocyte differentiation and that this upregulation was dependent on ERs and the ERK1/2 signaling pathways.

\section{Materials and Methods}

\section{Cell culture and treatments}

ATDC 5 cells, obtained by courtesy of Prof. Lin Chen (Third Military Medical University, Chongqing, China), were cultured and maintained in a 1:1 mixture of DMEM/F12 medium (Invitrogen) containing 5\% fetal bovine serum (FBS; Gibco) and $1 \%$ penicillin-streptomycin (Invitrogen) and incubated at $37^{\circ} \mathrm{C}$ in $5 \% \mathrm{CO}_{2} / 95 \%$ humidity. The cells were initially plated in six-well plates (Corning, New York, NY, USA) at a density of $6 \times 10^{4}$ cells/well. After reaching $70-80 \%$ confluency, cells were cultured with a differentiation medium, which was similar to the maintenance medium but with the addition of $1 \%$ insulin/transferrin/sodium selenite (ITS; Sigma). The day of addition of the differentiation medium was designated as day 0 and the differentiation medium was replaced every other day from days $2-14$. After 14 days, differentiation medium was removed and replaced with an ITS-free medium containing $0.5 \%$ FBS. The cells were incubated in the ITS-free medium for $24 \mathrm{~h}$ and then stimulated with $\mathrm{E}_{2}$ (Sigma) for another 24 or $48 \mathrm{~h}$.
Real-time PCR analysis

Following the differentiation protocol, total RNA was extracted from ATDC5 cells using a $1 \mathrm{ml}$ TRIzol reagent kit (Invitrogen). The total RNA was then dissolved in $0 \cdot 1 \%$ diethylpyrocarbonate water and quantified by spectrophotometry using a wavelength of $260 \mathrm{~nm}$. After quantification, $2 \mu \mathrm{g}$ total RNA was reverse transcribed into cDNA using a TaKaRa RNA PCR Kit version 2.1 (TaKaRa Biotechnology Dalian Co. Ltd., Dalian, China) according to the manufacturer's protocol. The sequences for primers (TaKaRa Biotechnology Dalian Co. Ltd.) used to amplify the mRNA were as follows: Obr: $5^{\prime}$-GACAGAACCAGCGCACACTGTTA-3' ${ }^{\prime}$ 5'-AAGCACTGAGTGACTCCACAGCA-3'; Col2 (Col2a1): 5'-GTCCTGAAGGTGCTCAAGGTTCTC-3'， 5'-AGGAATACCATCAGTCCCTGGGTTA-3'; Col10 (Col10a1): 5'-AGAACGGCACGCCTACGAT-3', $5^{\prime}$-CTGTGAGCTCCATGATTGCA-3'; and $\beta$-actin: 5'-CATCCGTAAAGACCTCTATGCCAAC-3', 5'-ATGGAGCCACCGATCCACA-3'. A LightCycler rapid thermal cycler system (Roche Diagnostics) was then used to perform quantitative real-time PCR using $1 \mu \mathrm{g}$ cDNA and SYBR Green (Bio-Bad) in 96-well plates according to the manufacturer's instructions. Melting curve analysis was performed using RotorGene 6.0 Analysis Software (Corbett Research, Sydney, Australia) to identify, analyze, and quantify the PCR products. The abundance of each gene product was normalized to $\beta$-actin and the $2^{-\Delta \Delta C_{t}}$ (cycle threshold) method was used to calculate relative gene expression levels as described previously (Maymo et al. 2010). The samples analyzed were generated from triplicate experiments and the results are expressed as fold change in gene expression normalized to a housekeeping gene ( $\beta$-actin) and relative to control conditions (untreated cultures).

\section{Western blot analysis}

ATDC5 cells were washed with PBS $(10 \mathrm{mM}, \mathrm{pH} 7 \cdot 4)$ and total protein was extracted using a Western \& IP Cell Lysis Kit (Beyotime, Shanghai, China). The concentration of protein in the cell lysate was determined using a Bio-Rad assay according to the manufacturer's protocol (Bio-Rad). For each sample, whole cell extracts equivalent to $40 \mu \mathrm{g}$ total protein were loaded into a $8 \%$ SDS-polyacrylamide gel, separated by electrophoresis, and the proteins electrotransferred to a polyvinylidene difluoride (PVDF) membrane (Bio-Rad). Nonspecific binding was blocked by incubating the PVDF membrane with $10 \mathrm{mM}$ TBS with $1.0 \%$ Tween 20 and $10 \%$ dehydrated skimmed milk. Following the blocking procedure, the membranes were incubated overnight with antibodies against OBR (Santa Cruz Biotechnology, Santa Cruz, CA, USA) or anti-phospho ERK1/2 (Cell Signaling Technology, Beverly, MA, USA) at $4{ }^{\circ} \mathrm{C}$. The performance of immunoblotting on the same membranes using antibodies against $\beta$-actin (Beyotime) or total-ERK1/2 (Cell Signaling Technology) was used as a loading control to assay the relative 
amounts of protein loaded into each gel. Following incubation with a primary antibody, the membranes were washed with TBST and incubated with alkaline phosphataselinked secondary antibodies (Jackson Immunoresearch, West Grove, PA, USA). The membranes were then washed once more and the immunoreactive bands visualized using NBT/BCIP as a substrate. Densitometric analysis was done using the NIH Image Software to quantify the protein present in the detected bands. $\beta$-actin content was assayed as standardization of sample loading. Quantitative densitometric values of each protein of interest were normalized to $\beta$-actin or to the nonphosphorylated form of the protein.

\section{Statistical analysis}

All data were presented as mean \pm s.E.M. for at least three independent experiments. Statistical analyses were performed using the SPSS 11.5 Statistical Software program (SPSS Inc, Chicago, IL, USA). Comparative studies of means between groups were determined by the one-way ANOVA followed by the least significant difference test or by the unpaired Student's $t$-test with a statistically significance at $P$ values $<0 \cdot 05$.

\section{Results}

\section{Differentiation of ATDC5 cells into chondrocytes}

We have evaluated ATDC5 cell proliferation and differentiation in vitro by light microscopy and typical chondrogenic differentiation markers (Fig. 1). As shown in Fig. 1A, from days 4 to 21 , ATDC5 cells proliferated gradually to form the typical cartilage nodules, which increased in size and number with time in culture. The expression of extracellular matrix genes, including those for type II and type $\mathrm{X}$ collagens, was used to characterize the chondrogenic differentiation of ATDC5 cells. Changes in the relative expression of these two chondrogenic differentiation markers were assayed using real-time PCR (Fig. 1B). The differentiation of mesenchymal cells into chondrocytes was indicated by an increase in Col2 expression in ATDC5 cells following a single day in the differentiation medium. The expression of Col2 continued to increase from days 4 to 14 , indicating the early stages of chondrocyte differentiation, and then decreased to nearbaseline levels from days 14 to 21 . The level of Col10 mRNA also increased but the effect was most noticeable starting on day 7, and the high level of Col10 expression was maintained during days 14 and 21, indicating the later stages of chondrocyte differentiation. By day 21, the expression of type II collagen in ATDC5 cells had been replaced by the expression of type $\mathrm{X}$ collagen. The expression pattern of chondrocyte differentiation markers indicates that undifferentiated ATDC5 cells can differentiate into proliferative chondrocytes and then to hypertrophic
A
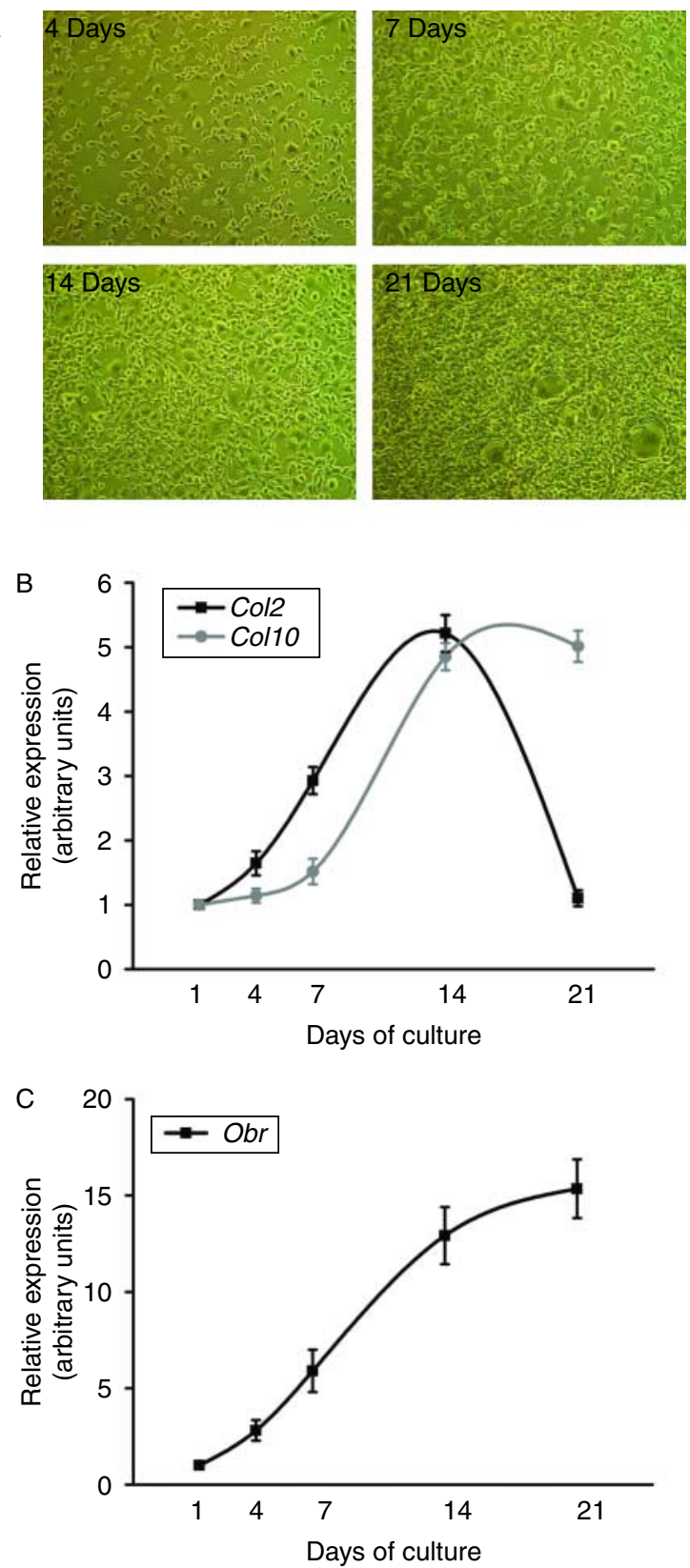

Figure 1 ATDC5 cell differentiation in culture. ATDC5 cells were cultured in six-well plates at a density of $6 \times 10^{4} /$ well in DMEM/F12 medium containing 5\% FBS and $1 \%$ ITS for $1,4,7,14$, and 21 days. (A) The size and number of the formed nodules were evaluated using light microscopy (10× magnification). Relative expression of collagen types II and X mRNA (B) and Obr mRNA (C) was determined by real-time PCR. Data represent mean \pm S.E.M. from triplicate samples in three independent experiments normalized against $\beta$-actin. Full colour version of this figure available via http://dx.doi.org/10.1530/JOE-11-0353.

chondrocytes under certain conditions. This result also validates the use of this cell line as an in vitro model that can be used to study chondrocyte differentiation. 
Expression of the leptin receptor in ATDC5 cells

We further examined changes in the expression of $\mathrm{Obr}$ during the differentiation of ATDC5 cells over 21 days. The results of real-time PCR confirmed that $\mathrm{Obr}$ mRNA was dynamically expressed in ATDC5 cells during all the differentiation phases (Fig. 1C). The levels of Obr mRNA increased sharply with the progression of chondrogenic differentiation (days 4-14) and then continued to increase but at a slower rate after day 14 during the hypertrophy stages, which was indicated by the change of predominant collagen expression from type II to type X (days 14-21).

\section{Effect of $E_{2}$ on leptin receptor in ATDC5 cells}

The role of $\mathrm{E}_{2}$ in regulating the expression of $\mathrm{Obr}$ in chondrocytes was determined by measuring the amount of Obr mRNA present in ATDC5 cells following treatment with $\mathrm{E}_{2}\left(10^{-7} \mathrm{M}\right)$ on day 14 . The cells were treated with $\mathrm{E}_{2}\left(10^{-7} \mathrm{M}\right)$ for 24 or $48 \mathrm{~h}$ and the expression of the $\mathrm{Obr}$ gene was analyzed by real-time PCR (Fig. 2A). When compared with control cells, no significant difference in the level of $\mathrm{Obr}$ mRNA was observed in ATDC5 cells after $24 \mathrm{~h}$ of exposure to $\mathrm{E}_{2}$. However, after $48 \mathrm{~h}$, the level of $\mathrm{Obr}$ mRNA was significantly increased in those cells stimulated with $\mathrm{E}_{2}$ compared with the control $(P<0 \cdot 05)$.

We then examined whether the changes in Obr mRNA expression were followed by a corresponding increase in protein level using western blotting on cells treated with $\mathrm{E}_{2}$ $\left(10^{-7} \mathrm{M}\right)$ for 24 and $48 \mathrm{~h}$ (Fig. $2 \mathrm{~B}$ and C). Similar to the mRNA expression level, no significant change in OBR protein expression was noted at $24 \mathrm{~h}$ after $\mathrm{E}_{2}$ stimulation. However, the presence of $\mathrm{E}_{2}$ significantly increased the level of OBR protein after $48 \mathrm{~h}$ of treatment compared with control cells $(P<0 \cdot 05)$. The results also showed that the level of OBR protein expression was significantly enhanced at $48 \mathrm{~h}$ after $E_{2}$ treatment in comparison to the level of protein expression before treatment $(0 \mathrm{~h} ; P<0 \cdot 05)$. The level of protein expression for the housekeeping protein, $\beta$-actin, was unchanged at all the time points examined. These data suggest that $E_{2}$ stimulation regulates the expression of $\mathrm{Obr}$ mRNA and consequently the changes of protein level.

To confirm whether the regulatory effect of $E_{2}$ on the expression of $\mathrm{Obr}$ mRNA occurred in a concentrationdependent manner, we treated ATDC5 cells with various concentrations of $E_{2}$ for $48 \mathrm{~h}$. Analysis of the results indicated that the concentration of $\mathrm{E}_{2}$ required to significantly increase the expression of $\mathrm{Obr}$ mRNA was in the range of $10^{-8}$ to $10^{-7} \mathrm{M}$, with a concentration of $10^{-7} \mathrm{M}$ being the most effective and $10^{-8} \mathrm{M}$ only slightly less effective (Fig. 3). Both concentrations produced an $\sim 150 \%$ increase in Obr mRNA expression. In addition, the application of $10^{-9}$ and $10^{-6} \mathrm{M}$ $\mathrm{E}_{2}$ produced increases in $\mathrm{Obr}$ mRNA expression that were not significant but were greater than control, indicating that the effect of $E_{2}$ was concentration dependent.
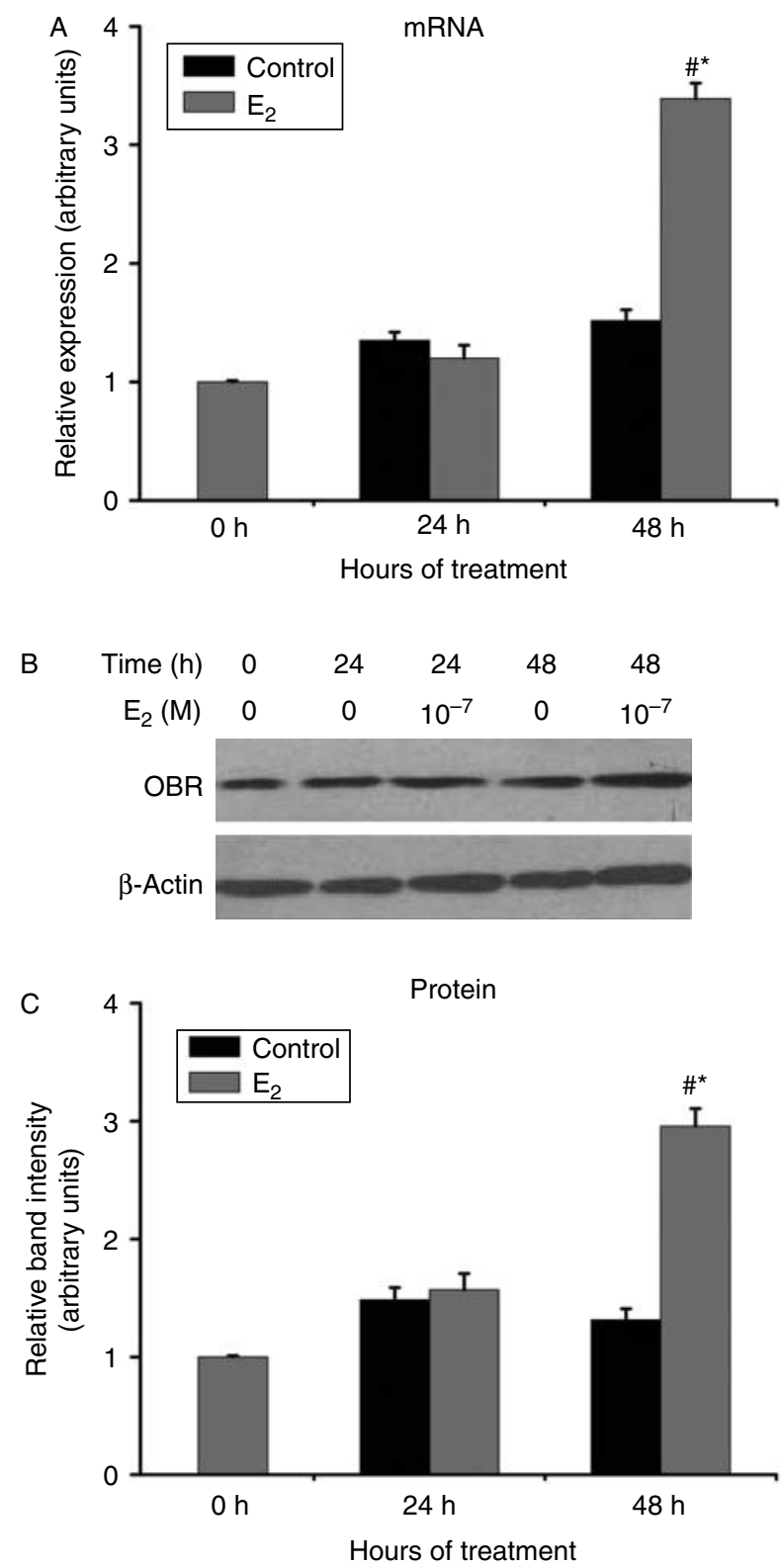

Figure 2 Effect of $E_{2}$ on OBR mRNA and protein. ATDC5 cells were cultured in DMEM/F12 containing 5\% FBS and $1 \%$ ITS in six-well plates at a density of $6 \times 10^{4} /$ well for 14 days. Cultured cells were then treated without and with $\mathrm{E}_{2}$ at $10^{-7} \mathrm{M}$ for 24 and $48 \mathrm{~h}$. Obr gene expressions (A) were analyzed by real-time PCR, normalized against $\beta$-actin, and compared with the control group. OBR protein levels were analyzed by western blot using specific antibodies as indicated. Bands (B) show representative western blots, whereas graphs $(C)$ show normalized data. Data represent mean \pm s.E.M. from triplicate samples in three independent experiments. ${ }^{*} P<0 \cdot 05$ vs control, ${ }^{\sharp} P<0 \cdot 05$ vs $0 \mathrm{~h}$.

To verify whether the gene regulation is through ER $\alpha$ or $\operatorname{ER} \beta$, cells were treated with the ER $\alpha$-selective agonist PPT $\left(4,4^{\prime}, 4^{\prime \prime}\right.$-(4-propyl-[1H]-pyrazole-1,3,5-triyl) trisphenol; $\left.10^{-7} \mathrm{M}\right)$ and the ER $\beta$-selective agonist DPN 


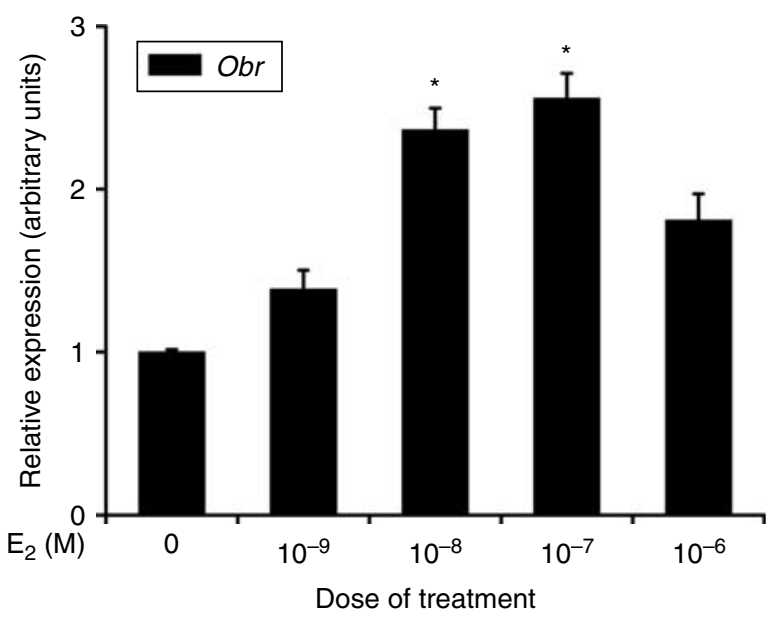

Figure 3 Effect of $\mathrm{E}_{2}$ on Obr mRNA expression in a dose-dependent manner. ATDC5 cells were cultured in DMEM/F12 containing $5 \%$ FBS and $1 \%$ ITS in six-well plates at a density of $6 \times 10^{4} /$ well for 14 days. Cultured cells were then treated without and with $E_{2}$ at $10^{-9}, 10^{-8}, 10^{-7}$, and $10^{-6} \mathrm{M}$ for $48 \mathrm{~h}$. Obr gene expressions were analyzed by real-time PCR, normalized against $\beta$-actin, and compared with the control group. Data represent mean \pm s.E.M. from triplicate samples in three independent experiments. ${ }^{*} P<0 \cdot 05$ vs control.

(2,3-bis(4-hydroxyphenyl)-propionitrile; $\left.10^{-7} \mathrm{M}\right)$. PPT and DPN were obtained from Tocris Bioscience (Ellisville, MO, USA). OBR mRNA and protein levels were significantly upregulated at $48 \mathrm{~h}$ after PPT stimulation $(P<0 \cdot 05)$ at day 14. However, no significant difference was found after DPN treatment (Fig. 4A and B).

As type $\mathrm{X}$ collagen is expressed exclusively by mature chondrocytes, and its expression is a differentiation marker of the ATDC5 cell model, we treated the cells with $\mathrm{E}_{2}$, PPT, and DPN at $10^{-7} \mathrm{M}$ for $24 \mathrm{~h}$ at day 14; a significant increase in Col10 mRNA levels was observed after $\mathrm{E}_{2}$ or PPT stimulation (Fig. 5).

\section{Activation of ERK signaling by $E_{2}$ in ATDC5 cells}

Using western blotting in ATDC5 cells, we next performed a time-course experiment to identify whether $\mathrm{E}_{2}$ can activate the phosphorylation of ERK1/2 in a time-dependent manner on day 14. After treatment of ATDC5 cells with $10^{-7} \mathrm{M} \mathrm{E}_{2}$, a rapid and transient phosphorylation of ERK1/2 was detected from $5 \mathrm{~min}$ and peaked at the $10 \mathrm{~min}$ time point and then gradually declined to basal levels within $60 \mathrm{~min}$ (Fig. 6A and B). A maximum fourfold stimulation was observed at $10 \mathrm{~min}$. The protein levels of the internal controls, total ERK1/2 and $\beta$-actin, remained unchanged between samples.

\section{Role of ERs and ERK signaling in $E_{2}$-induced expression of leptin receptors}

Our earlier research suggested that the ERK pathway should have an important role in the chondrocyte differentiation process and indicated that this pathway should be activated by ER stimulation. In order to analyze the involvement of ERK1/2 in $\mathrm{E}_{2}$-induced expression of $\mathrm{Obr}$, we used an inhibitor of ERK1/2 (U0126; Cell Signaling Technology) and an antagonist of ERs (ICI 182 780; Tocris Bioscience)

A
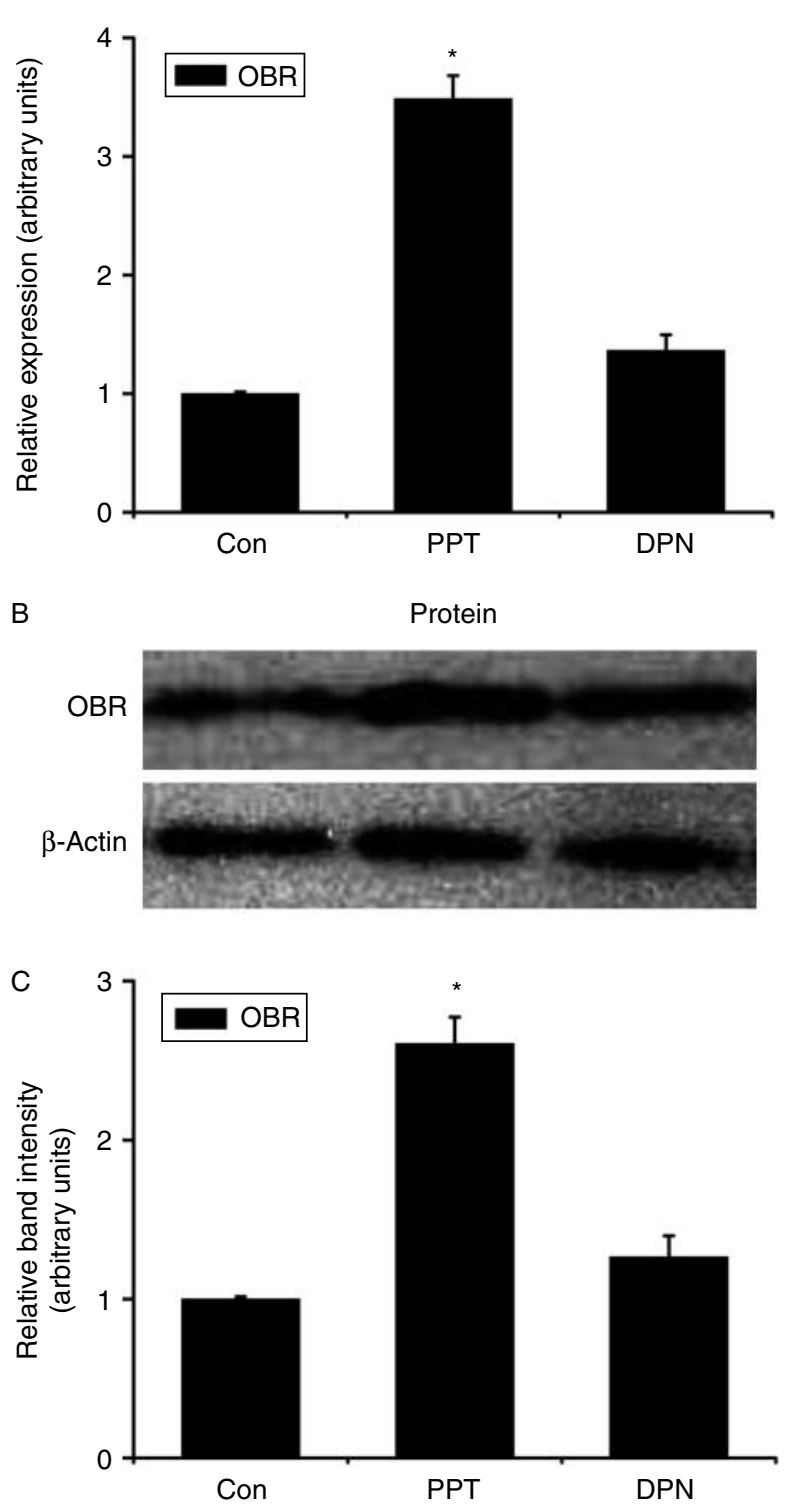

Figure 4 Effect of PPT and DPN on OBR mRNA and protein. ATDC5 cells were cultured in DMEM/F12 containing 5\% FBS and $1 \%$ ITS in six-well plates at a density of $6 \times 10^{4} /$ well for 14 days. Cultured cells were then treated without and with PPT or DPN at $10^{-7} \mathrm{M}$ for $48 \mathrm{~h}$. Obr gene expressions (A) were analyzed by real-time PCR, normalized against $\beta$-actin, and compared with the control group. OBR protein levels were analyzed by western blot using specific antibodies as indicated. Bands (B) show representative western blots, whereas graphs (C) show normalized data. Data represent mean \pm S.E.M. from triplicate samples in three independent experiments. $* P<0 \cdot 05$ vs control. 


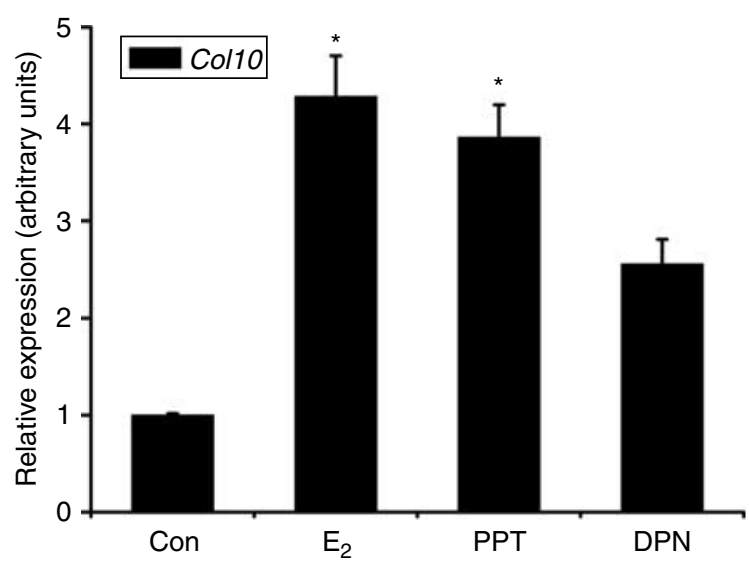

Figure 5 Effect of $E_{2}$, PPT, and DPN on Col10 mRNA. ATDC5 cells were cultured in DMEM/F12 containing $5 \%$ FBS and $1 \%$ ITS in sixwell plates at a density of $6 \times 10^{4} /$ well for 14 days. Cultured cells were then treated without and with $\mathrm{E}_{2}, \mathrm{PPT}$, or DPN at $10^{-7} \mathrm{M}$ for $24 \mathrm{~h}$. Col10 gene expressions were analyzed by real-time PCR, normalized against $\beta$-actin, and compared with the control group. Data represent mean \pm S.E.M. from triplicate samples in three independent experiments. ${ }^{*} P<0 \cdot 05$ vs control.

to examine their effects on $\mathrm{E}_{2}$-induced phosphorylation of ERK1/2 by western blotting. Cells were pretreated with U0126 $(5$ or $20 \mu \mathrm{M})$ and ICI $182780(1 \mu \mathrm{M})$ for $90 \mathrm{~min}$ and then incubated with or without $\mathrm{E}_{2}\left(10^{-7} \mathrm{M}\right)$ for $10 \mathrm{~min}$ (Fig. 4C and D). The application of U0126 suppressed the effect of $E_{2}$ on ERK1/2 phosphorylation in ATDC5 cells in a concentration-dependent manner. Even the lowest concentration of U0126 used $(5 \mu \mathrm{M})$ significantly decreased the phosphorylation of ERK $1 / 2$ by $80 \%$ compared with the no inhibitor-treated cells $(P<0 \cdot 05)$. Similarly, treatment with ICI 182780 prevented $\mathrm{E}_{2}$-induced increases in the amount of p-ER K1/2 protein. However, neither U0126 nor ICI 182780 changed the total amounts of ERK1 and ERK2 proteins. These results confirmed that ERK phosphorylation occurs as a result of ER-mediated activation of ERK signaling.

In order to demonstrate that the $\mathrm{E}_{2}$-induced expression of the $\mathrm{Obr}$ gene is dependent on the increase in ERK phosphorylation resulting from ER activation, ATDC5 cells were pretreated with U0126 $(20 \mu \mathrm{M})$ or ICI $182780(1 \mu \mathrm{M})$ for $90 \mathrm{~min}$ and then incubated with $\mathrm{E}_{2}\left(10^{-7}\right)$ for $48 \mathrm{~h}$. The alterations in $\mathrm{Obr}$ expression produced by this treatment were quantified using real-time PCR and western blotting. Analysis of the results indicated that the upregulation of OBR mRNA and protein expression mediated by $\mathrm{E}_{2}$ was significantly blocked by U0126 or ICI 182780 (Fig. 7A and $\mathrm{B} ; P<0 \cdot 05)$, in agreement with the effect of $\mathrm{E}_{2}$-mediated phosphorylation of ERK1/2. Treatment with ICI 182780 or U0126 alone did not alter the steady-state level of OBR mRNA or protein. Taken together, these results strongly suggest that estrogen exerts its effect through the action of ERs on $\mathrm{Obr}$ expression and reinforce the notion that $\mathrm{E}_{2}$ has a role in regulating $\mathrm{OBR} \mathrm{mRNA}$ and protein expression via the ERK1/2 pathway.

\section{Discussion}

The activation of OBR in growth plate chondrocytes modulates several events associated with the differentiation and maturation of chondrocytes (Nakajima et al. 2003, Kishida et al. 2005). In this study, experiments in the chondrogenic ATDC5 cell line have elucidated for the first time some of the mechanisms whereby estrogen was able to regulate the OBR. The results of the study showed that OBR was dynamically expressed during chondrocyte differentiation in increasing amounts and that the application of $E_{2}$ for $48 \mathrm{~h}$ on day 14 could upregulate both OBR mRNA and protein during the middle stages of differentiation. This effect was mediated through the activation of ERs and induction of the ERK1/2 signaling pathway.

The ATDC5 cell line is an excellent growth plate chondrocyte model. The use of this model was validated in our study with the cells expressing chondrogenic markers in a relevant progression over a 21-day period. In particular, cells initially experienced an increase in the expression of mRNA of type II collagen, which is the predominant extracellular matrix in the proliferating stage and coincides with the differentiation phase. The increase in type II collagen was then reversed, whereas the expression of collagen was dominated by type $\mathrm{X}$, a unique marker in the hypertrophic stage of growth plate chondrocytes. This pattern of collagen expression in ATDC5 cells is in agreement with previously reported results (Nakajima et al. 2009, Challa et al. 2010, Snelling et al. 2010). Therefore, the change in collagen type II and $\mathrm{X}$ expressions clearly define two critical events that occur during cartilage formation: the early differentiation of committed stem cells into chondrocytes and the terminal differentiation of proliferating to hypertrophic chondrocytes. Thus, we investigated the role of $\mathrm{E}_{2}$ in $\mathrm{Obr}$ expression during differentiation at day 14 , a time point where the maximum amounts of both types of collagen were expressed, which occurs during the middle stage between the generation of proliferative and prehypertrophic chondrocytes.

In parallel with the results of collagen expression analysis, we also confirmed that ATDC5 cells express OBR starting from the first day of culture and steadily increasing over the next 21 days as the cells move through the various differentiation phases. This observation is consistent with results from a previous study in which ATDC5 cells were cultured for 6 weeks (Kishida et al. 2005). The finding that the expression of $\mathrm{Obr}$ increases over the differentiation stages suggests that OBR may mediate different functions. This study also provided evidence that $\mathrm{Obr}$ expression could be regulated by $\mathrm{E}_{2}$ (Fig. 2). The concentration of $\mathrm{E}_{2}$ used in the study was selected based on the study by Kato et al. (2010) who used $10^{-7} \mathrm{M} \mathrm{E}_{2}$ to demonstrate a cross talk between $\mathrm{ER} \alpha$ and the P38/MAPK pathway in ATDC5 cells. Rodd et al. (2004) also indicated that only $10^{-7} \mathrm{M} \mathrm{E}_{2}$ was capable of inducing the maturation of prehypertrophic chondrocytes into the hypertrophic phenotype, which was associated with 
A
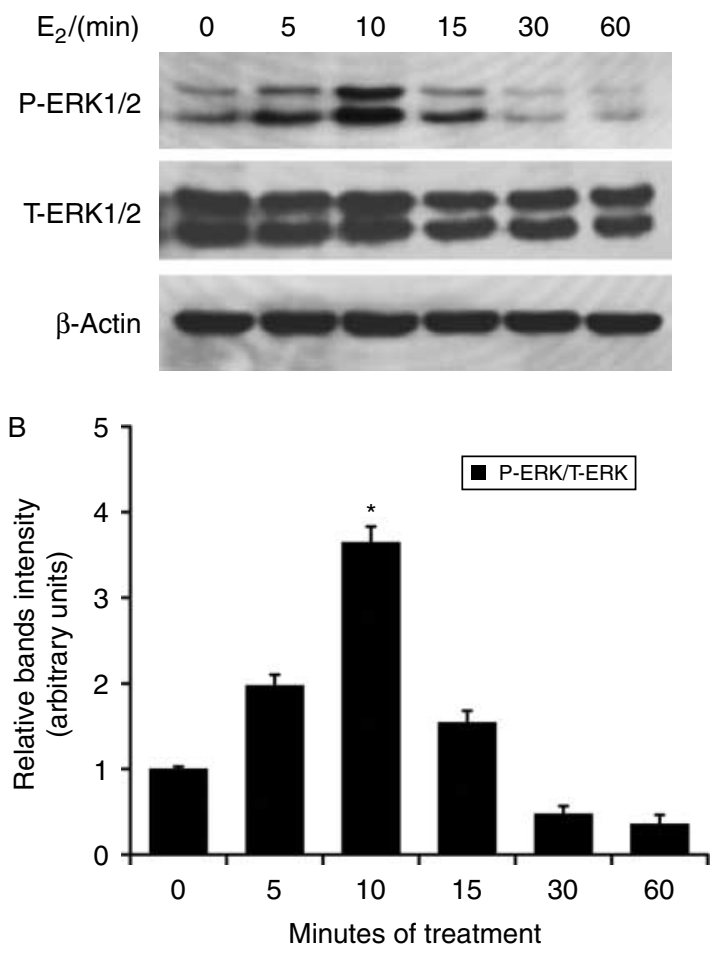

C $\mathrm{U} 0126(\mu \mathrm{M}) \quad 0 \quad 5 \quad 20 \quad 0 \quad 0 \quad 20$

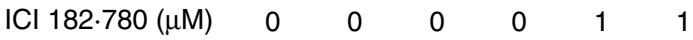

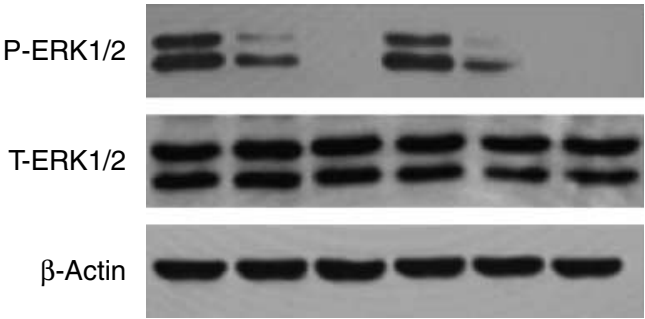

D

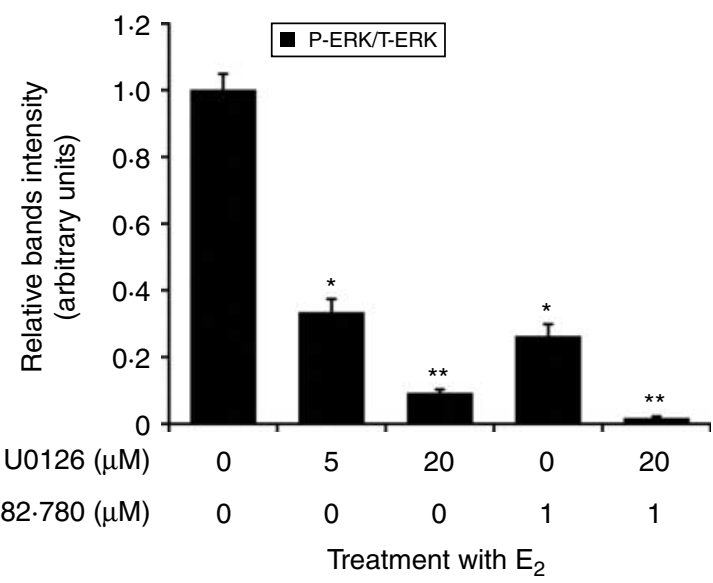

Figure 6 Effect of $E_{2}$ on ERK1/2 phosphorylation levels. ATDC5 cells were cultured in DMEM/F12 containing $5 \%$ FBS and $1 \%$ ITS in six-well plates at a density of $6 \times 10^{4}$ /well for 14 days. (A and B) Cultured cells were treated with $10^{-7} \mathrm{M} \mathrm{E}_{2}$ for indicated times. P-ERK1/2 and ERK1/2 protein levels were analyzed by western blot. Bands (A) show representative western blots, whereas graphs (B) show normalized data. (C and D) Cultured cells were treated with U0126 (5 and $20 \mu \mathrm{M})$ and ICI $182780(1 \mu \mathrm{M})$ for $90 \mathrm{~min}$ and then treated with $10^{-7} \mathrm{M} \mathrm{E}_{2}$ for $10 \mathrm{~min}$. P-ERK1/2 and ERK1/2 protein levels were analyzed by western blot. Bands (C) show representative western blots, whereas graphs (D) show normalized data. Data represent mean \pm s.E.M. from triplicate samples in three independent experiments. ${ }^{*} P<0 \cdot 05$ vs control, ${ }^{* *} P<0 \cdot 01$ vs control.

the appearance of type $\mathrm{X}$ collagen in bovine fetal epiphyseal growth plate chondrocytes. Here we have reconfirmed those results as our application of increased concentrations of $E_{2}$ from $10^{-9}$ to $10^{-6} \mathrm{M}$ resulted in a concentration-dependent change in $\mathrm{Obr}$ mRNA, with $10^{-7} \mathrm{M}$ being the most effective (Fig. 3). Interestingly, both the lower and higher concentrations of $\mathrm{E}_{2}$ had a similar effect producing a bell-shaped effect curve whereby the Obr gene expression profiles suggested that the optimal effects of $E_{2}$ occur within a narrow range.

One hypothesis for the narrow concentration window for $\mathrm{E}_{2}$ activity in relation to $\mathrm{Obr}$ expression is that the effects of estrogen are mediated through several opposite pathways. During longitudinal bone growth, $\operatorname{ER} \alpha$ stimulates bone growth while ER $\beta$ inhibits bone growth (Chagin et al. 2004, Perry et al. 2008, Borjesson et al. 2010). In addition, ER $\beta$ can antagonize ER $\alpha$ activity in some species and tissues, evidence that supports a 'yin yang' relationship between $\operatorname{ER} \beta$ and ER $\alpha$ (Perry et al. 2008). For example, at low concentrations of estrogen, $\mathrm{ER} \beta$ is able to inhibit $\mathrm{ER} \alpha$-activated transcription from estrogen response elements. In contrast, at high concentrations of a ligand, $\mathrm{ER} \beta$ does not inhibit $\mathrm{ER} \alpha$ action; moreover, it induces its own transcription (Hall \& McDonnell 1999). Thus, at different concentrations of estrogen, ER $\beta$ might have the capacity to promote different effects. Using mouse mammary epithelial cells, Helguero et al. (2005) showed that activation of ER $\beta$ opposes ER $\alpha$-induced proliferation and increases apoptosis. Other studies have focused on the ratio of the $E R \alpha$ to $E R \beta$ expression (Shin et al. 2007, Yi et al. 2008) and showed that the ratio of $E R \alpha$ to $E R \beta$ expression in adipocytes is an important potential regulatory factor in leptin expression. As discussed above, the reported ability of $\operatorname{ER} \beta$ to antagonize ER $\alpha$ activity adds complexity to the interpretation of this experiment; therefore, the functions of the two subtypes in ATDC5 cell were to be defined in this study. We used PPT and DPN to examine the selective role of ER $\alpha$ and $\operatorname{ER} \beta$ in regulation of OBR in ATDC5 cells and found that PPT was more effective than DNP on $\mathrm{Obr}$ 
expression. It could thus be speculated that the effect of $E_{2}$ on OBR in ATDC5 cells was predominantly through the actions on ER $\alpha$.

In addition to the fact that $\mathrm{E}_{2}$ only has an effect within a narrow concentration range, the application of $\mathrm{E}_{2}$ for 24 or

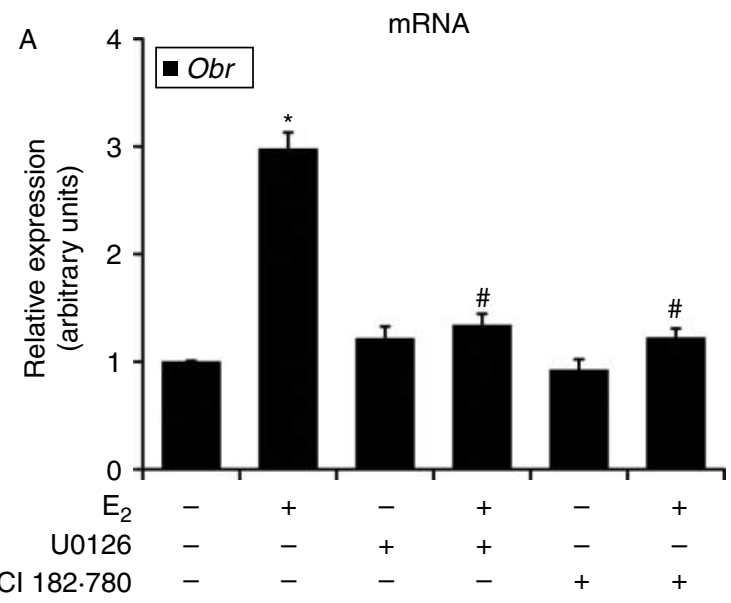

B
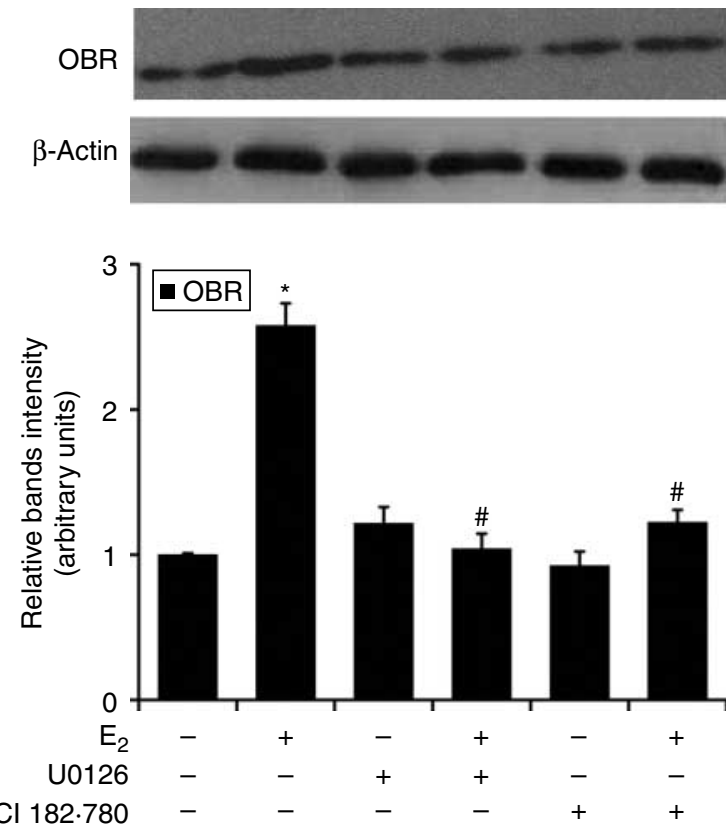

Figure 7 Effect of $\mathrm{U} 0126$ and $\mathrm{ICl} 182780$ on $\mathrm{E}_{2}$-induced $\mathrm{Obr}$ expression. ATDC 5 cells were cultured in DMEM/F12 containing $5 \%$ FBS and $1 \%$ ITS in six-well plates at a density of $6 \times 10^{4} /$ well for 14 days. Cultured cells were pretreated with UO126 $(20 \mu \mathrm{M})$ and $\mathrm{ICI}$ $182780(1 \mu \mathrm{M})$ for 90 min followed by treatment with $10^{-7} \mathrm{ME}_{2}$ for 48 h. (A) Obr gene expressions were analyzed by real-time PCR, normalized against $\beta$-actin, and compared with the control group. (B) OBR protein levels were analyzed by western blot using specific antibodies as indicated. Bands show representative western blots, whereas graphs show normalized data. Data represent mean \pm s.E.M. from triplicate samples in three independent experiments. ${ }^{*} P<0 \cdot 05$ vs control, ${ }^{\sharp} P<0 \cdot 05$ vs noninhibited control.
$48 \mathrm{~h}$ to ATDC5 cells shows that $48 \mathrm{~h}$ stimulation is required to produce a significant change in mRNA and consequent protein levels. Different mechanisms may be involved during the first $24 \mathrm{~h}$ of $\mathrm{E}_{2}$ exposure vs the latter half of the $48 \mathrm{~h}$ cell culture. From our observation that $24 \mathrm{~h}$ exposure to $\mathrm{E}_{2}$ did not induce significant change in OBR mRNA and protein, we speculated that $E_{2}$ may indirectly stimulate the level of OBR mRNA and protein. This delay in the positive regulation of $\mathrm{OBR}$ by $\mathrm{E}_{2}$ during middle-stage chondrogenesis could be related to transcription levels and stability of $\mathrm{Obr}$ mRNA. The late response of protein suggested that the regulation may take place through an intermediate gene product, but the precise molecular mechanisms by which this effect is only seen following exposure for $48 \mathrm{~h}$ are not clear. Another possible explanation may be due to intracellular changes in the ATDC5 cells. Albrecht et al. (2009) found that in vitro culture conditions changed dramatically with time, and this change would influence the expression profile of the hormones and their receptors that are involved during the growth and differentiation of growth plate chondrocytes. In this study, we replaced the culture medium every other day $(48 \mathrm{~h})$ to lessen its influence; hence, we did not analyze receptor activation at additional time points such as 72 and $96 \mathrm{~h}$.

Studies indicated that the MAPK pathway involving ERK (ERK1 and ERK2) played a critical role in chondrocyte differentiation as inhibition of ERK1/2 signaling with U0126 blocked insulin-induced chondrogenesis (Nakajima et al. 2004, Phornphutkul et al. 2006). It is also well known that ERs can initiate various phosphorylation-related signal transduction cascades (Acconcia \& Kumar 2006). Thus, we hypothesized that the upregulation of $\mathrm{OBR}$ by $\mathrm{E}_{2}$ was due to an increase in ERK1/2 caused by $E_{2}$ acting at ERs. Our results showed that $E_{2}$ strongly activated the ERK1/2 pathway in ATDC5 cells and that the resultant ERK1/2 phosphorylation could be blocked in a dose-dependent manner by U0126. These findings were consistent with a previous report demonstrating that $\mathrm{E}_{2}$ caused a rapid phosphorylation of ERK1/2 at $9 \mathrm{~min}$ in rat growth plate chondrocytes (McMillan et al. 2006). Similarly, the application of the ER inhibitor ICI 182780 blocked the $\mathrm{E}_{2}$-mediated upregulation of OBR. These observations indicated that activation of ERK1/2 and functional ERs is essential for $\mathrm{E}_{2}$-induced $\mathrm{Obr}$ expression during chondrogenic differentiation of ATDC5 cells. However, the molecular mechanisms about how ERK mediates the effects of $E_{2}$ on Obr expression are unknown. ERK1/2 should not be the unique pathway activated in the ATDC5 cells, we believe, and multiple signaling pathways may be involved potentially in the regulation of chondrocyte differentiation.

In conclusion, this study indicated that $\mathrm{Obr}$ expression in chondrocytes increases over the duration of the cell differentiation process, and this expression could be upregulated by $\mathrm{E}_{2}$ in a leptin-independent manner requiring the presence of ERs. Furthermore, our findings suggested that this upregulation by $\mathrm{E}_{2}$ was mediated through ERK signaling 
pathways. The results of our research may have significant implications in understanding the mechanisms of longitudinal bone growth, but further studies are needed to confirm our findings and define the other possible mechanisms involved.

\section{Declaration of interest}

The authors declare that there is no conflict of interest that could be perceived as prejudicing the impartiality of the research reported.

\section{Funding}

This work was supported by the National Natural Science Foundation of China (30901508, U1032001).

\section{References}

Acconcia F \& Kumar R 2006 Signaling regulation of genomic and nongenomic functions of estrogen receptors. Cancer Letters 238 1-14. (doi:10.1016/j.canlet.2005.06.018)

Albrecht C, Helmreich M, Tichy B, Marlovits S, Plasenzotti R, Egerbacher M \& Haeusler G 2009 Impact of 3D-culture on the expression of differentiation markers and hormone receptors in growth plate chondrocytes as compared to articular chondrocytes. International Journal of Molecular Medicine 23 347-355. (doi: 10.3892/ijmm_00000138)

Ben-Eliezer M, Phillip M \& Gat-Yablonski G 2007 Leptin regulates chondrogenic differentiation in ATDC5 cell-line through JAK/STAT and MAPK pathways. Endocrine 32 235-244. (doi:10.1007/s12020-007-9025-y)

Bertoni L, Ferretti M, Cavani F, Zavatti M, Resca E, Benelli A \& Palumbo C 2009 Leptin increases growth of primary ossification centers in fetal mice. Journal of Anatomy 215 577-583. (doi:10.1111/j.1469-7580.2009.01134.x)

Borjesson AE, Lagerquist MK, Liu C, Shao R, Windahl SH, Karlsson C, Sjogren K, Moverare-Skrtic S, Antal MC, Krust A et al. 2010 The role of estrogen receptor $\alpha$ in growth plate cartilage for longitudinal bone growth. Journal of Bone and Mineral Research 25 2414-2424. (doi:10.1002/jbmr.156)

Chagin AS, Lindberg MK, Andersson N, Moverare S, Gustafsson JA, Savendahl L \& Ohlsson C 2004 Estrogen receptor- $\beta$ inhibits skeletal growth and has the capacity to mediate growth plate fusion in female mice. Journal of Bone and Mineral Research 19 72-77. (doi:10.1359/jbmr.0301203)

Challa TD, Rais Y \& Ornan EM 2010 Effect of adiponectin on ATDC5 proliferation, differentiation and signaling pathways. Molecular and Cellular Endocrinology 323 282-291. (doi:10.1016/j.mce.2010.03.025)

D'Eon TM, Souza SC, Aronovitz M, Obin MS, Fried SK \& Greenberg AS 2005 Estrogen regulation of adiposity and fuel partitioning. Evidence of genomic and non-genomic regulation of lipogenic and oxidative pathways. Journal of Biological Chemistry 280 35983-35991. (doi:10.1074/jbc. M507339200)

van der Eerden BC, Gevers EF, Lowik CW, Karperien M \& Wit JM 2002 Expression of estrogen receptor $\alpha$ and $\beta$ in the epiphyseal plate of the rat. Bone 30 478-485. (doi:10.1016/S8756-3282(01)00703-7)

Ekstein J, Nasatzky E, Boyan BD, Ornoy A \& Schwartz Z 2005 Growth-plate chondrocytes respond to $17 \beta$-estradiol with sex-specific increases in IP3 and intracellular calcium ion signalling via a capacitative entry mechanism. Steroids 70 775-786. (doi:10.1016/j.steroids.2005.04.007)

Fruhbeck G 2006 Intracellular signalling pathways activated by leptin. Biochemical Journal 393 7-20. (doi:10.1042/BJ20051578)

Fusco R, Galgani M, Procaccini C, Franco R, Pirozzi G, Fucci L, Laccetti P \& Matarese G 2010 Cellular and molecular crosstalk between leptin receptor and estrogen receptor- $\{\alpha\}$ in breast cancer: molecular basis for a novel therapeutic setting. Endocrine-Related Cancer 17 373-382. (doi:10.1677/ERC-09-0340)
Galal N, El Beialy W, Deyama Y, Yoshimura Y, Yoshikawa T, Suzuki K \& Totsuka Y 2008 Effect of estrogen on bone resorption and inflammation in the temporomandibular joint cellular elements. International Journal of Molecular Medicine 21 785-790.

Gambino YP, Maymo JL, Perez-Perez A, Duenas JL, Sanchez-Margalet V, Calvo JC \& Varone CL 2010 17 $\beta$-Estradiol enhances leptin expression in human placental cells through genomic and nongenomic actions. Biology of Reproduction 83 42-51. (doi:10.1095/biolreprod.110.083535)

Gao Q \& Horvath TL 2008 Cross-talk between estrogen and leptin signaling in the hypothalamus. American Journal of Physiology. Endocrinology and Metabolism 294 E817-E826. (doi:10.1152/ajpendo.00733.2007)

Gat-Yablonski G \& Phillip M 2008 Leptin and regulation of linear growth. Current Opinion in Clinical Nutrition and Metabolic Care 11 303-308. (doi:10.1097/MCO.0b013e3282f795cf)

Hall JM \& McDonnell DP 1999 The estrogen receptor $\beta$-isoform (ER $\beta$ ) of the human estrogen receptor modulates ER $\alpha$ transcriptional activity and is a key regulator of the cellular response to estrogens and antiestrogens. Endocrinology 140 5566-5578. (doi:10.1210/en.140.12.5566)

Helguero LA, Faulds MH, Gustafsson JA \& Haldosen LA 2005 Estrogen receptors alfa $(E R \alpha)$ and $\beta(E R \beta)$ differentially regulate proliferation and apoptosis of the normal murine mammary epithelial cell line HC11. Oncogene 24 6605-6616. (doi:10.1038/sj.onc.1208807)

Kato M, Takaishi H, Yoda M, Tohmonda T, Takito J, Fujita N, Hosogane N, Horiuchi K, Kimura T, Okada Y et al. 2010 GRIP1 enhances estrogen receptor $\boldsymbol{\alpha}$-dependent extracellular matrix gene expression in chondrogenic cells. Osteoarthritis and Cartilage 18 934-941. (doi:10.1016/j.joca.2010.03.008)

Kishida Y, Hirao M, Tamai N, Nampei A, Fujimoto T, Nakase T, Shimizu N, Yoshikawa H \& Myoui A 2005 Leptin regulates chondrocyte differentiation and matrix maturation during endochondral ossification. Bone 37 607-621. (doi:10.1016/j.bone.2005.05.009)

Li XF, Wang SJ, Jiang LS \& Dai LY 2012 Gender- and region-specific variations of estrogen receptor $\alpha$ and $\beta$ expression in the growth plate of spine and limb during development and adulthood. Histochemistry and Cell Biology 137 79-95. (doi:10.1007/s00418-011-0877-0)

Maeso Fortuny MC, Brito Diaz B \& Cabrera de Leon A 2006 Leptin, estrogens and cancer. Mini Reviews in Medicinal Chemistry 6 897-907. (doi:10.2174/138955706777934973)

Mayes JS \& Watson GH 2004 Direct effects of sex steroid hormones on adipose tissues and obesity. Obesity Reviews 5 197-216. (doi:10.1111/ j.1467-789X.2004.00152.x)

Maymo JL, Perez Perez A, Duenas JL, Calvo JC, Sanchez-Margalet V \& Varone CL 2010 Regulation of placental leptin expression by cyclic adenosine $5^{\prime}$-monophosphate involves cross talk between protein kinase A and mitogen-activated protein kinase signaling pathways. Endocrinology 151 3738-3751. (doi:10.1210/en.2010-0064)

McMillan J, Fatehi-Sedeh S, Sylvia VL, Bingham V, Zhong M, Boyan BD \& Schwartz Z 2006 Sex-specific regulation of growth plate chondrocytes by estrogen is via multiple MAP kinase signaling pathways. Biochimica et Biophysica Acta 1763 381-392. (doi:10.1016/j.bbamcr.2006.02.010)

Meli R, Pacilio M, Raso GM, Esposito E, Coppola A, Nasti A, Di Carlo C, Nappi C \& Di Carlo R 2004 Estrogen and raloxifene modulate leptin and its receptor in hypothalamus and adipose tissue from ovariectomized rats. Endocrinology 145 3115-3121. (doi:10.1210/en.2004-0129)

Nakajima R, Inada H, Koike T \& Yamano T 2003 Effects of leptin to cultured growth plate chondrocytes. Hormone Research 60 91-98. (doi:10.1159/000071877)

Nakajima M, Negishi Y, Tanaka H \& Kawashima K 2004 p21(Cip-1/SDI-1/ WAF-1) expression via the mitogen-activated protein kinase signaling pathway in insulin-induced chondrogenic differentiation of ATDC5 cells. Biochemical and Biophysical Research Communications 320 1069-1075. (doi:10.1016/j.bbrc.2004.06.057)

Nakajima S, Naruto T, Miyamae T, Imagawa T, Mori M, Nishimaki S \& Yokota S 2009 Interleukin-6 inhibits early differentiation of ATDC5 chondrogenic progenitor cells. Cytokine 47 91-97. (doi:10.1016/j.cyto.2009.05.002)

Nilsson O, Abad V, Chrysis D, Ritzen EM, Savendahl L \& Baron J 2002 Estrogen receptor $-\alpha$ and $-\beta$ are expressed throughout postnatal development in the rat and rabbit growth plate. Journal of Endocrinology 173 407-414. (doi:10.1677/joe.0.1730407) 
Nilsson O, Chrysis D, Pajulo O, Boman A, Holst M, Rubinstein J, Martin Ritzen E \& Savendahl L 2003 Localization of estrogen receptors- $\alpha$ and $-\beta$ and androgen receptor in the human growth plate at different pubertal stages. Journal of Endocrinology 177 319-326. (doi:10.1677/joe.0.1770319)

Perry RJ, Farquharson C \& Ahmed SF 2008 The role of sex steroids in controlling pubertal growth. Clinical Endocrinology 68 4-15. (doi:10.1111/ j.1365-2265.2007.02960.x)

Phornphutkul C, Wu KY \& Gruppuso PA 2006 The role of insulin in chondrogenesis. Molecular and Cellular Endocrinology 249 107-115. (doi:10.1016/j.mce.2006.02.002)

Ray A, Nkhata KJ \& Cleary MP 2007 Effects of leptin on human breast cancer cell lines in relationship to estrogen receptor and HER 2 status. International Journal of Oncology 30 1499-1509.

Rodd C, Jourdain N \& Alini M 2004 Action of estradiol on epiphyseal growth plate chondrocytes. Calcified Tissue International 75 214-224. (doi:10.1007/ s00223-004-0197-7)

Shin JH, Hur JY, Seo HS, Jeong YA, Lee JK, Oh MJ, Kim T, Saw HS \& Kim SH 2007 The ratio of estrogen receptor $\alpha$ to estrogen receptor $\beta$ in adipose tissue is associated with leptin production and obesity. Steroids $\mathbf{7 2}$ 592-599. (doi:10.1016/j.steroids.2007.03.013)

Snelling SJ, Hulley PA \& Loughlin J 2010 BMP5 activates multiple signaling pathways and promotes chondrogenic differentiation in the ATDC5 growth plate model. Growth Factors 28 268-279. (doi:10.3109/ $08977191003752296)$
Sylvia VL, Walton J, Lopez D, Dean DD, Boyan BD \& Schwartz Z 2001 $17 \beta$-estradiol-BSA conjugates and $17 \beta$-estradiol regulate growth plate chondrocytes by common membrane associated mechanisms involving PKC dependent and independent signal transduction. Journal of Cellular Biochemistry 81 413-429. (doi:10.1002/1097-4644(20010601)81:3<413:: AID-JCB1055>3.0.CO;2-M)

Wang SJ, Jiang LS \& Dai LY 2012 Leptin regulates estrogen receptor gene expression in ATDC5 cells through the extracellular signal regulated kinase signaling pathway. Journal of Cellular Biochemistry. In press. (doi:10.1002/jcb. 24005)

Windahl SH, Lagerquist MK, Andersson N, Jochems C, Kallkopf A, Hakansson C, Inzunza J, Gustafsson JA, van der Saag PT, Carlsten H et al. 2007 Identification of target cells for the genomic effects of estrogens in bone. Endocrinology 148 5688-5695. (doi:10.1210/en.2007-0508)

Yi KW, Shin JH, Seo HS, Lee JK, Oh MJ, Kim T, Saw HS, Kim SH \& Hur JY 2008 Role of estrogen receptor- $\alpha$ and $-\beta$ in regulating leptin expression in 3T3-L1 adipocytes. Obesity 16 2393-2399. (doi:10.1038/oby.2008.389)

Received in final form 16 February 2012

Accepted 6 March 2012

Made available online as an Accepted Preprint

6 March 2012 